\title{
EL AÑo QUE VIENE
}

Ha caído una nevisca, no la esperaba.

Todavía oscuro, creí que llovía, que

lo que golpeaba en el techo translúcido

era la lluvia,

y pensé en el día gris que venía.

De repente vi la pureza blanca,

el asomo a una paz, lo quieto del jardín

cubierto por una pelusa,

una gasa de blancura entredejando manchones verdes,

desde la cocina,

en pendiente hacia arriba, hacia la calle

entre las ramas ahora peladas,

desde el oscuridero.

En el césped queda el trazo fino del venado,

que hace cuna en la película de nieve,

su huella al descubierto.

Lo blanco es una ligereza.

Atrás, una capa de cuentas desparramadas

en la terraza de cristal. Me asomo.

No se puede pisar sin que suene.

$*$

\section{EL AÑO QUE LLEGA}

Como una plancha de plata bulle el día, un pescado en la sartén del amanecer, crepitando entre el frío y el calor, con la marea naranja del sol inundando los mástiles de árboles blanqueando el horno del paisaje. Un aceite de niebla lame las varas de romero, 
los aros de cebolla chisporroteando, la hojarasquería que ruge hacia su consumación.

No es hambre lo que bulle en las tripas

de esta olla de invierno, sino la proyección de caldos continuos, la carne blanca y las espinas y huesos, el halo plateado de las hojas, el paisaje en que estamos. No es hambre lo que nos trae aquí, sino el vaho común que se concentra, su producción en todo.

\section{Plan de Tlacapatla}

Un jacal en que entráramos, techado de niños, carbón al viento o basurillas en los pajares del maizal. En medio las vacas, a la partida de los peones, sin hibernación ni guarida, olisqueando huellas humanas, ruido sólo nosotros.

En los escombros, un camioncito sin ruedas, mechas de palma, un bule roto y tres piedras tiznadas en señal del hogar.

Sobras de trashumancia, después de la siembra, al cabo de la pizca. 